\title{
Kashmir and Its Economy under Hindu Rule (Ancient Period)
}

\author{
Manzoor Ahmad \\ E-mail: bhatmanzoorg@gmail.com
}

Received: August 9, 2014 Accepted: September 22, $2014 \quad$ Published: November 23, 2014

doi:10.5296/ijch.v1i2.6661

URL: http://dx.doi.org/10.5296/ijch.v1i2.6661

\begin{abstract}
The valley of Kashmir is truly a dream of beauty, set in the heart of Himalayas. The land came to be known after the name of Sage Kashayapa as "Kashayapmar". The name was born out from two Sanskrit words "Ka" (water) and "Shimira" (Dry up) i.e. dried up land. The valley like other territories of the world too passed through pre and proto-historical periods of study. Under the proto-historical period it witnessed ancient, medieval and modern ages. During the period under discussion the economy of the land which functioned a key to the fiscal policy of the rulers witnessed many ups and downs. The people engaged in agriculture, industry and trade as prime factors of its economy experienced various hardships. There was no end to their miseries as majority of the rulers through their revenue agencies sucked their blood by imposing vicious taxes over them.
\end{abstract}

Keywords: Ka, Shimira, Proto-history, Legend, Scientific, Satisar, Agraharas, Anapati

\section{Introduction}

Kashmir is an extensive alluvial vale bounded on the west by Suliman Mountains, on the east, south-east by the River Sutlaj and on the north by the Himalayas. Whosoever is looking at the map of vast Himalayan region is sure to find many delightful valleys and picturesque spots. But among all these Kashmir is unique in her flora and fauna, history, culture and art. To be precise it is one of the most beautiful and fertile valleys in the world. It is situated at latitude $33^{0} .15$ and $34^{0} .35$ north and longitude $74^{\circ}, 10$ and $75^{\circ}, 40$ east covering an area of 84 miles by 25 miles in expanse with almost a uniform height of 1500-1800mts above sea level. The origin of the valley of Kashmir is told in several romantic legends and myths. The valley as per these legends was originally a mighty lake called "Satisar". The earliest work which has recorded the tradition, is the Nilmatpurana written by Kashmiri Brahmans in $6^{\text {th }}, 7^{\text {th }}$ century AD. It recorded Kashmir was originally a vast lake and continued for millions of years. How this lake dried up and the resultant bottom came to be known as Kashmir, possess two evidences (1) Legends (2) Scientific. 
Legends:-As per legend in the "Satisar" lake there lived a demon Jaladhabhava, who caused a great distress to all neighboring regions by his devastations. The sage Kiashyapa, the father of all Nags while on his pilgrimage in the north of India heard of this distress from his son Nila who lived in the valley. The sage determined to punish the evil doer proceeded to Brahma to implore his and other god's help for this purpose. All the gods by Brahma's command started for Satisar and took up their positions on the lofty peaks above KaunsarNaag. The demon refused to come forth from the lake. There upon Vishnu called on his brother Blabhdra' to drain out the lake, which he did by making a breach at Baramulla, ultimately water receded and the lake dried up. Joladhbhava was attacked by Vishnu and slain with his war disc. Kashayapa then settled the land. The land came to be known after the name of sage Kashayapa as Kashaypmar, which today is known as Kashmir.

Scientific (Geological):-The scientific studies carried out by geologists, geochemists since 1864, produced a vast literature on the geological ages of Kashmir. They hold that the valley was formed out of a series of geological changes based on a huge geological material found in the valley which come down to us in shape of flat topped plateaus known in Kashmir as woudar (Karewas). After studying the structure and composition of these wudars the scientists are unanimous that Kashmir was a lake for millions of years. It shifted towards the north and northern-east side around $3500000 \mathrm{BC}$ and ultimately started draining out about $83000 \mathrm{BC}$ their conclusions were mainly based on the structure and composition of the wudars (karewas). There are two types of karewas in Kashmir designated by the geologists as:- (1) Lower karewas situating towards the south and south-west of Kashmir as represented by Hirpure formation in District Shopain and (2) Upper karewas situating towards north and north-east of Kashmir as represented by Nagam formation in District Budgam. The marked difference between the lower and upper karewas is seen in their thickness of Aeolian deposition of Loess. The loess thickness of lower kaewas is 25-30mts with paloesols, while its thickness is 10mts with paloesols on the upper karewas. The same is visible at ShirpurPattan, Beerue, Budgam, Burzahome etc. This variation is the proof that the lake continued to be in force on the Himalayan flank until the late Ice Age and the loess started depositing on this side only after the lake was finally drained out. As per the Radio Carbon-14 dating of these loess deposits, the older loess that forms the ground surface in the north-western Kashmir dates back to $29000 \mathrm{BC}$ and the young loess which forms the ground surface in the north-eastern Kashmir is not older than 18000 years. Since then the valley floor was not yet desiccated. It is in this younger loess that the Neolithic man excavated his dwellings which have been encountered at Burzahome and Gufkral. Such settlement pattern existed up to $200 \mathrm{BC}$ as all the early settlements have been found on the wudars (karewas).

Like other parts of the world in Kashmir too, man's march towards civilization started with the Paleolithic Age. The archeological investigation under the guidance of Grinlinton a German at Lidder valley in 1928AD recovered a "handmade" boulder. This evidence has established the existence of stone culture in Kashmir on firm footing. The same has been supported by H.D Sankalia in 1969. The tools recovered there were claimed of the earliest Paleolithic period in Asia. A few chopper type tools and scrapers were recovered from Prang Waswan (Sindh valley) Balapure in Shopian. The existence of the Paleolithic culture in 
Kashmir of a different nature had been revealed by blade and burin industry at Sombar $18 \mathrm{kms}$ south-east of Srinagar. The tools recovered there were burins, points and borers. Similarly other tools of the period were found at Kulladar, Bhatchak, Tapriballa in District Baramulla, Khansahib and Habshasahib in District Budgam. The presence of burins, points, strongly support the idea that man stared stitching the animal hides to cover his body. Archeological Department of India while excavating at Manasbal hold, that the caves found there were the deviling places of Paleolithic man in Kashmir. It was by 3000BC climate became warmer in Kashmir. This led the influx of people from the neighboring areas, who were primitive farmers. With this Kashmir entered into the Neolithic Age (New Stone Age). The archeologists have divided the Neolithic culture in Kashmir into three periods:

I) $2800-2250 \mathrm{BC}$

II) $2250-2000 \mathrm{BC}$

III) $2000-1500 \mathrm{BC}$

On the basis of advancement made by the Neolithic men in the field of technology, life standard and economy. The main features of the culture were domestication of plants and animals, manufacture of delicate ground stone tools and pottery, emergence of village communities based on sedentary life. Nearly three dozen Neolithic sites have been identified in Kashmir but only two of these Burzhome and Gufkral have been excavated and mentioned in the literary annals of history, which too were left unprotected. The Neolithic culture in Kashmir was succeeded by Megalithic culture during which huge memorial stones were erected. The remains of which have been found at many places like Burzhome, Gutkral, Hariparigam, Begund, Pahalgam, Brah etc. while at Waztal Tarakpur, Sombur, Pampur, Dadsara etc. no such relics have been found. The period ranging from 1000-700 BC has been ascribed to the Megalithic in Kashmir. The period witnessed the introduction of technology, improvement of tools, houses, pottery and monuments. The excavation at Gufkral reveals a good number of iron objects in the form of points, rods, copper rings. Besides this a fine cobbler's Awl was recovered there. Despite this the people were still accustomed of living on the wudars (karewas) due to the fact that the low lying areas were still covered with water or were marshy.

The most significant information about the early historical period has come from the Semthan (District Anantnag) excavation (1981). It showed the inhabitants lived in hutments, as bone beads, several pieces of copper and evidence of grain was recovered from the site. It further referred the existence of pine, cedar and walnut. The cultural phase of the period definitely points to the arrival of a new set of people as Pre-Northern Black polished ware (PNBPW) Northern Black Polished ware (NBPW) and Indo-Greeks were found. The immigrants were Aryans who entered Kashmir via swat valley. The earliest history of Kashmir has been recorded by kalhana in "Rajtarangini" which opens with the year 1184 BC from the reign of "Mighty Gonada" the king of Kashmir. He hold the view that fifty two (52) kings ruled Kashmir in earliest period, but he had given the name of only four, Gonada I, his son Damodara I, Damoara's wife Yasomati and her son Gonada II. They were followed by 35 kings whom Kalhana called lost kings, as nothing was known about their historicity. It is with 
pride kalhana mentioned the first historical name who ruled Kashmir and the same has been cleared by the semthon excavation was Ashoka of the Mouryan period (273-232 BC) who conquered Kashmir in $250 \mathrm{BC}$, introduced Buddhism and founded the city of Srinagar, presently at Pandrethan in the vicinity of Shankeracharya hill. The Mouryans were succeeded by the Indo-Greeks, the Sakas, the Indo-Parithanes, Huns etc till the first local dynasty called the Karkotas got reins of government in their own hands, which was succeeded by other dynasties of the land to the end of Hindu rule, Kotarani being the last one (1339AD).

It is impossible to generalize the economic condition which prevailed in Kashmir from the origin of ruler and ruled relationship developed to the end of Hindu rule. It is natural that under benevolent kings the country prospered and the people were happy, while under oppressive ones they passed through agony and destitute. The same has been discussed under the following heads to provide an extensive information in this aspect of human life.

\section{Agriculture}

Agriculture greatly contributed to the progress of human civilization. During the Neolithic period man started a settled life, which was accompanied by domestication of animals and plants. The period witnessed the cultivation of soil which provided the basic needs to man in shape of food, clothing and shelter I.e. agriculture functioned the backbone of man's economy. Blessed by nature with fertile soil, temperate climate, water resources and consequently easy cultivation Kashmir has been known as "a paradise for agriculturists". Kalhana in Rajtarangini mentioned that in the valley majority of population lived in villages that were deeply tied to agriculture. Owing to the isolated nature of the valley as land locked by high mountains, the agriculture was organized on the basis of self- sufficiency of villages. The communication of the valley with other parts of the country to purchase a few necessities of life like salt and iron was limited. The cultivators raised crops of food grains particularly of rice, barely, pulses, fruits and saffron. The crops were produced by using simple tools which included wooden plough and sickle as referred in NilmatPurana and Rajtarangini. The plough was driven with the help of oxen. Besides oxen the villagers reared cows, sheep and goat which provided them milk and wool. Further Kashmir has been known for fruits since early times. The town of Narpur and Jayavana (Zewan) has been mentioned by Kalhana of possessing beautiful gardens. Hieun Tsang had noticed, peer, plum, peach, apricot and grapes. Alberuni mentioned in Tahqiq-i-Hind that a basket of flowers was sent to somnath temple daily from Kashmir for worship.

Agriculture on plain land needed systematic irrigation and fertilization. The valley being fortunate, possessing water resources in abundance, functioned a key to its economic progress. However there were certain areas where water scarcity was felt in the period. King Suvarna in the pre-Ashokan Age constructed a canal called Suvarnamani (modern Sunmun kul), it irrigated a part of the Advin Pargana situated on the alluvial pleateau to the south of Ramyar river in the District Kulgam. Lalitaditya (724-61) AD of the Karkota dynasty is noted in the history of Kashmir for introduction of new methods of irrigation i.e. construction of water wheels (counter lift) as utilized by the Indus people also. Due to this method he brought more land under cultivation especially the plateau of Tsakdar (Cakradhara) near vijbror (Bejbhara). 
In addition to it some kings like Damodra, Bladitya and Lalitaditya tried their best to protect the cultivable land from floods by the construction of embankments, which saved the cultivators from this eventuality. But under the rule of their successors the situation worsened. It goes to the credit of Avantivermen (855-883) $\mathrm{AD}$, who took a series of reforms which healed the wounds of the suffering people. The ruler utilized the services of his able minister Suyya who has been titled Anapati (Lord of food). M.A.Stien summarized the methods as introduced by Suyya to achieve the desired goal. It was a herculean task of dredging and widening. He constructed high embankments on the both sides of the river in order to check the rocks and boulders from falling into the river. These steps accelerated the flow of water and thereby checked the threat of inundation. Further he changed the junction of the Vitasta (Jhelum) river and its tributary the Sindh River from Trigam in the Lar Pargan (District Gandarbal) to Srinagar and regulated the course of water of the river in such a way that it flowed right through the Mahapadma Lake which passed through embankments constructed by the government. He also regulated the water of other rivers and reclaimed thousands of acres of land for agriculture. In addition to these he had taken samples of soil from each village and noticed the time taken by each sample to dry up. Accordingly he distributed the water for irrigation to each village. The culminative effect of these steps increased the agricultural production in Kashmir and thereby brought economic prosperity to the people. Kalhana in Rajtarangini mentioned that a kharwar $(80 \mathrm{~kg})$ of rice was sold for 36 dinars (coins) during the period while in normal times during his predecessors was sold at 200 dinars (coins) and in abnormal times 1050 dinars (coins). These steps immortalized Avantivarman by the name of Engineer King. But under the succeeding dynasties the glory lost its legs especially under Lohara dynasty from 1003 AD onwards, which showed the signs of decline. Most of its rulers were cruel, selfish and sensual. They brought nothing but miseries to the people of the valley.

\section{Ownership of Land}

As per Nilamata Purana, on the land which emerged out of water as a result of desiccation of Satisar Lake, a number of gods, sages and other people built their abodes. It revealed that in the beginning land was plentiful and freely available. In due course of time, when the population increased the land acquired its value. At the birth of ruler and ruled concept, the ownership of land was affixed to the king being the communal head. With the passage of time on the bifurcation of the communal and royal jurisdictions, the institution of private property developed. Consequently he (king) became the owner of one of the three categories as per the land system prevalent in the valley i.e. royal. An extensive study of the literary sources made it clear that the land in Kashmir was divided in three categories private, communal and royal.

\section{Private}

There are various instances of transfer of land by sale and gift in the history of Kashmir.

1) In the $6^{\text {th }}$ century AD Pravarasena II a king of Kashmir blessed a wondering Brahman named Jayanta. With the blessings of the king he became rich and turned his wealth to the pious use by establishing "Agraharas". The revenue of which was assigned to an individual or religious institution. (2) During $8^{\text {th }}$ century AD king Candrapida wished to build a temple 
at a site where there was leather tanner's hut over it. He purchased the land including the hut from the owner then constructed a temple there in accordance with the law. This reveals that there was a specific official whose duty was to record the sale of the land. (3) In the case of Jayyaka of Selyapure village during king Kalsa $\left(11^{\text {th }}\right.$ century AD) clearly showed that cultivable land was bought and sold. (4) During the rule of king Jayasimha $12^{\text {th }}$ century AD we come across several ministers who owned large tracts of land which they bestowed on the Brahmans as Agraharas. This clearly showed that property rights of individuals were supported and protected by the state.

\section{Communal}

The grazing grounds around a village were used and owned by the villagers in common. In the time of Jayasimha his revenue minister Citraratha had confiscated even the gazed land (caraka) of the sacred cows for the sake of revenue. But soon after the lands were released for free grazing.

\section{Royal}

The royal lands including forests, mines and the fallow land. The king made religious grants of the rest and emerged royal estates, the cultivation of which was arranged by the king himself. In the time of king Sussala $12^{\text {th }}$ century these estates were so extensive that even the fodder for the horses of his army came from his own land further the king was a titular owner of the remaining cultivated lands whose right was limited to a share in their produce. This is evident that the cultivated lands were held by the peasants against the proper payment of the annual land revenue.

\section{Source of Revenue}

In order to meet the expanses of the civil administration, the government resorted to taxation of various kinds. As the economy of the country depended mainly on agriculture and the land revenue functioned the main source of income which was exacted at the rate of $1 / 6$ of the total produce in normal times and during the period of later Hindu kings the same has been raised to $1 / 2$ of the total produce. There are references that during king Lalitadatiya who said, "Every care should be taken that there should not be left with the villagers more food supply than required for one year consumption." The land revenue was generally calculated in grain as viewed by Abul fazal, who showed that the revenue administration in kashmir during the Mughal period coincide with the time of Hindu kings as well. The references to the office of Gramakayastha (village accountant) and Skandaka (lambardar) indicate the existence of a record showing a cultivator's holdings and his revenue liabilities. The cultivators could not remove their produce from the thrashing ground until the state share had been taken from it, as special watchmen were employed by the government at the fields. The system was not beneficial to the cultivators as reported by kalhana. Thus the revenue collected was stored in state granaries. The same was distributed among the people at fixed rates during emergency. In addition to the land revenue the people were required to pay other taxes as well, which multiplied during Samkaravarman, Didda, Sangramaraja, Ananta, Harsa, Sussla and Jayasimha. These additional imposts caused depreciation in the position of tax payers. 
Sankaravarman established two new revenue offices called Attapatibhaga (the lord of market) and Grahakrtya (domestic affairs) who imposed taxes on market and domestic affairs. During king Susal, Ananda, the lord of gate imposed taxes on marriage, Yajnopavita (sacred thread cermony) and on other festive occasions. He also introduced beggar (force labor) though it has been referred in the Indian history since Mouryas as discussed by Kautalya at length and regarded it a lawful privilege of the government. As a result of Sankarvarman's fiscal policy, kalhana says the villagers were driven to extreme poverty and breathing was the only activity which remained free from these taxes. Due to instability which prevailed in the $10^{\text {th }}$ and $11^{\text {th }}$ century by the intrusion of Muslim conquerors it impoverished the people and revenue receipts dwindled. The govt. introduced more unjust methods of taxation, king Harsa plundered the temples and oppressed the householders. The people were oppressively taxed and a separate department for collection of tax on night soil was established. Those who denied paying were tormented.

The evolution of taxation system in Kashmir as outlined is a reflex of the growth of royal power and the king's demands on his subjects' purse. He found the normal taxes were inadequate to meet his needs. Therefore he under took to regulate numerous domestic and economic activities which formed a profitable source of income for him. The policy necessitated the employment of a large bureaucracy. The requirement put an additional burden on the state exchequer which was met with new levies. Despite this the royal treasury fell short of money due to the disparity of taxation system during Hindu kings as they were in the habit of bestowing the large tracts of fertile land as free grants on numerous Brahmans and their corporations who were given exemption from the payment of all taxes. Its effect on the royal exchequer was extreme harmful. The lot of cultivators was thus most unenviable; they lived in a condition of abject poverty. The villagers had to take rice or dry barley in husks and wild growing vegetable of bitter taste called Utpalasaka. To sum up the taxation system under Hindu kings was highly irrational and in equitable. Its incidence was mainly borne by the cultivators and ordinary householders who passed through miserable conditions under their wretched rule.

\section{Industry}

Though agriculture was the occupation of the majority of the people in Kashmir yet various industries also absorbed a fair proportion of them. Every house in a village was the centre of a small industry but the gradual urbanization favoured the concentration of industrial arts in the towns. It was the result of urbanization that several arts and crafts developed and made significant progress. But there were no factories or large enterprises of the modern sense, nor karkhanas of the Mughal times. Broadly speaking there were three types of industries which existed in Kashmir during the period under discussion, the same were:-

1) Peasant Arts and Crafts:-These were pursued by the peasants during their spare time or off season in winter when they could not work in open due to intense cold or snow, which were hand-spinning, weaving, rice pounding, making of baskets, ropes etc.

2) Village Subsistence Industries: - These had actually little to do with agriculture but still their existence depended on the fortunes of agriculture. The work of village blacksmiths, 
carpenters, weavers, oil pressers and potters who used to fulfill the simple needs of the villagers.

3) Urban Arts and Crafts:- These were carried on by artisans, family members inside their homes, representing a higher standard of local art and creativeness. The artisans turned out such products for the use of towns-folk as textiles, metal work, stonework, woodwork, leather goods, jewellary, confectionery etc.

Of all these industries, textiles seem to have attained a high degree of excellence. In one of the tiles of Harvan, a lady is seen robed in transparent clothes. Hieun Tsang also spoke of this industry in glowing terms. From his writings it appeared that there were three main types of clothing used by the people; the first was Kauseya which covered various kinds of silk and muslin, the second Ksauma or linen manufactured from flax and hemp and the third Kambala, implying woolen blankets and other kinds of cloth made from the wool of goats and similar other animals. A variety of woolen blankets and garments such as Lohita-kambala, Sthulia-kambala, Parvara and Kutha were referred to in Ksemendras's Narmanla and Samayamatrka and in Kalhana's Rajtarangini. The industry also presupposed the existence of a section of prople devoted to pasture. It is evident that they have taken up cattle rearing as their profession. Kalhana referred to the fact that pattana (modern pattan) which was a cloth weaving centre and also a centre for the purchase and sale of cattle.

Smithary was an important industry in the valley. The people engaged in it mostly manufactured a variety of tools employed in agriculture, domestic utensils of copper and brass, temple bells and war weapons. Some images recovered at various places in the valley speak a high standard of craftsmanship which the workers had achieved. Further there were numerous references in Rajatarangini to gold bangles, armlets, rings and other ornaments worn by kings, queens and other people for personal adornment. Closely connected with a metal industry was that of pottery. A large quantity of earthen ware of the Neolithic period has been recovered from Burzahome and at Awantipore, Jar, Ghara, Handi Jug, Bowl, Kangir, Incense burners, bottle and earthen lump which belong to $9^{\text {th }}$ century AD. Some terracotta heads discovered at ushkar too spoke of the art. Ksemendra even mentioned the earthen rings which adorned the ears of poor classes. These multitudes of facts go a long way to show that pottery as an industry was in a thriving condition. Among other industries worthy to mention were leather work, wood work and stone work. Ksemendra spoke of leather water bag as an important item in the camp luggage of a Kayastha officer; while kalhana referred that a leather worker charged 100 dinars for repairing a torn shoe and a whip. The manufacturing of boats, carriages, palanquins and other types of conveyances and household furniture had provided employment to a good number of workers. Similarly the presence of numerous ruins of grand and massive stone temples and beautiful old images testify to the existence of a large number of masons and sculptures and their admirable mastery to the skill in their profession. The minor professions included those of gardeners, fisherman, garland makers, barbers and different types of artisans formed various classes of the society and earned their livelihood.

\section{Trade and Commerce}

Kashmir had political and cultural contacts with distant corners of India, central Asia, Tibet 
and China. Under Ashoka and Kanshika Kashmir became a part of vast empires and being geographically situated at a central and strategic position in Asia, it became the meeting place of caravans (commercial class) from the plains of India and of distant cities in central Asia. The same had given a boost to its trade practices both internal and external which may be discussed as:-

\section{Internal Trade:-}

The indication of regular arranged markets or Hattas at many places in the valley showed that a brisk trade was carried on internally from the earliest period. The city of Pravapura, founded by Pravaseena II regularly arranged markets on the right bank of river Jhelum. From the king Sussala (1111-1120 AD) there had come up "market streets" throughout the city. Kalhana mentioned, king Nara built the town of Narpur where markets were kept full of supplies. The navigation had given splendor to the river Jhelum. Besides the transactions in the markets, goods were sold by roaming hawkers also. These hawkers included both men and women, who carried their victuals in baskets over their heads. The society being mainly rural with the villages as its self-sufficient base unit, the trade between towns and villages remain limited due to the difficult means of transportation and remained confined to a few articles like salt and iron for the supply of which the villagers depended upon the towns. The woolen goods, food grains, cattle, iron implements, earthen wares metallic vessels, leather goods, saffron, grape wine etc. being the principle natural and industrial products of the country. It is logically consistent to presume that these formed the chief articles of trade. Similarly the towns and cities of Pravarapur (srinagar), Parihaspur, Puranadhisthana, Hushkapur, Jayapur, Samkarapattan (pattan), Awantipur and suyapura (sopore) emerged as great commercial centers. River Jhelum and its tributaries served the chief highways and boats, the principle means by which the internal trade was carried on in the valley. Rajtarangini frequently alludes to the river journeys, boats, boat bridges and Ghats (landing places). Thus it is evident that Jhelum played an important role in the commercial life of Kashmir as most of the cities and towns were situated on its banks. The indigenous bankers performed the business of finance. They received deposits and gave loans on interest against the pledge of movable or immovable property as well as personal surety. Even kings obtained loans from these bankers. Anantadeva king of Kashmir took loans by mortgaging his crown and throne. Hundies or indigenous bills of exchange were made use of. Kalhana mentioned in his writings that as early as $10^{\text {th }}$ century proper year wise accounts of loans and advances were maintained with the help of professional accounts. It was after the scrutiny of such account books that king Yasakara was able to expose the dishonesty of a merchant.

\section{External Trade:-}

The external trade of Kashmir was carried by various routes leading to India, central Asia, Tibet and china. The chief of these went from Baramulla to Gandhara, another route ran from north shore of wular lake to Astor and Balti territories on the Indus and the third route leading through the Zojila pass to Ladakh and then to Tibet and China. To India there led several other routes through Pirpanjal range, chief among these passed through the Banihal pass which linked up Kashmir with Punjab to the west of Banihal pass lay the pass of Sidhapatha 
which directly connected Srinagar with Sialkot in Punjab. The last important route across the Pirpunjal range passed through the Tosomaidan pass which joined Srinagar to lohara and then led to the valley of Poonch. It has been mentioned that under Kushan rule Kashmir became the hub of central Asian region in trade transaction and with India from the days of Ashoka. The import and export trade of the valley was carried by the routes mentioned above. The chief articles of import were salt, spices, cotton, precious metals, copper and brass for coin age from india. Marcopolo mentioned that coral which was carried from the western parts of the world had a better sale in Kashmir. There is no exaggeration to mention that in $7^{\text {th }}$ century AD Kashmir was full of merchants who had come from all regions. Strict rules prevalent in the state led to the peaceful condition which gave a fillip to trade especially under Yasaskara (939-948 AD) and Hariraja as the land was cleared of robbers and thieves. Besides the entreport trade Kashmir also exported its own products such as woolen goods, saffron, Kuth (costus) and small quantity of silk. The demand for the Kashmiri saffron in Indian markets was great in ancient times as referred in "Ratnavali" of Harsha. Hieun Tsang noticed woolens being worn by the people of northern regions of India. Kashmir being a center of woolen manufacture and had a brisk export trade in this commodity. Further Kashmir is known for Shawls since ancient times, the raw-wool came from the high land of Tibet. These regions owing to high altitude are intensely cold and nature has clothed the goats there with warm wool. The wool traders exchanged their raw-wool for manufactured Shawls and sold these advantageously in various markets of central Asia, where from they were carried to famous cities of Asia and Europe. Hieun Tsang found Kashmiris weaving cloth of white linen, but there is no reference that cotton was grown in Kashmir. Kaslhana mentioned in Rajtarangini that printed cotton cloth of various designs and qualities was imported from Ceylon (Sri Lanka). Further Sandalwood, betel-leaves were imported from India and horses from central Asia and Afghanistan. King Sussala was so fond of these, that foreign horse dealers grew rich under him. Though means of communication were scant yet, fruits were exported to the markets of northern India. Abul Fazal in Ain-i-Akbari mentioned that Kashmiris' bring grapes on their backs in big baskets. It was on the basis of their great demand that the fruit was exported either fresh or in dried form. Each of the mountain passes had a watch station (Dranga) at the end of the route, where custom officers were posted to collect duties. All the goods passing through these stations were properly stamped and registered. Soldiers were posted at these stations for safe guarding the routes against any inroad, as after $10^{\text {th }}$ century the threat from outside increased being northern India attacked by the Muslims. They even in $11^{\text {th }}$ century made their intrusion to the valley under Mohammad of Ghazni. Though it was nature which saved the territory from his onslaughts yet it affected the trade of Kashmir with the outer world badly.

\section{Medium of Exchange}

In Kashmir, the literary sources tell us that Cowrie shells and Dhanya (paddy) were used as medium of exchange from the early times. The cowrie shell was in fact used throughout india in ancient times. Ksemendra and Kalhana mentioned in their writings that the land revenue, fine, wages etc. were paid in paddy being an essential commodity in Kashmir and acceptable to all. The earliest coins discovered in the valley belong to the indo Greeks, the Scythians and 
the Parthians. Under Kushan rule, Kashmir shared the prosperity of the great empire. The overland routes were open, which enriched the valley and raised her economic standard to high level. It was during this flourishing period that the Roman gold being ultimately minted into Kushan coins became current in Kashmir, a few of which were housed in Srinagar Museum. The gold coins were adopted for carrying on trade with foreign countries, as they accept nothing except gold. Copper coins were the medium of exchange in local transaction. A large number of these coins have been found at distant places like Utter Pradesh and Bihar, showing the brisk trade of Kashmir with the rest of India during the period.

Kalhana, Jonaraja, Srivera and Ksemendra refer to the term Dinnar corresponding to our cash or currency. From $9^{\text {th }}$ century onwards there is no evidence that gold coins were in actual circulation, as trade with foreign countries came to standstill due to instability. It is clear from the beginning of $10^{\text {th }}$ century onwards Kashmir had a coin age of copper only. The measure of weight in Kashmir has been the Khari from immemorial times. There are references to it in Kalhana's Rajitarangini, Ksemendra's Lokaprakasa and Ain-i-Akbari of Abul Fazal. This ancient measure has been mentioned even in hymns of Rig-Veda (IV 32, 17). The division and weight of Khari does not appear to have changed to the recent past. According to Abul Fazal and Moorcraft a Khari is equal to1920palas ( $80 \mathrm{kgs}$ ). Land measures were calculated not by length and breadth but by the quantity of seed required by certain areas for the rice cultivation. A Khari of land exactly corresponds to four acres of the British.

\section{Conclusion}

It is evident that due to scant sources of the pre-historic period, it is difficult to frame a solid opinion about the concept. However on the basis of available sources regarding the proto-historic period it is clear that during King Lalitadatiya (724-761AD) of the Karkota dynasty Kashmir has risen to a pitch of glory and under Awantivarman it witnessed the period of marked consolidation but his son and successor Sankarvarman met with a dismal failure, as he sealed the passes to save his kingdom from being conquered by the Muslims of North India. It reduced the people of Kashmir to the plight of beleaguered garrison. The resources of the small kingdom were too poor to fulfill its needs. External trade declined which increased pressure on agricultural land. Consequently the rulers take recourse to the imposition of numerous taxes to meet the expenses of their courts and large standing army. They even turned their attention to temples their endowments and sacred gold, silver and copper statues of gods and goddesses which they melted for the purpose of coin age to stabilize their financial condition. The kingdom passed through vicious circle, the masses were reduced to poverty, and the state revenues dwindled. Kashmir was at a large unfortunate under the rulers of the period and the people had to endure unspeakable miseries at the hands of several tyrants. Kalhana in Rajtarangini presented gruesome pictures of kings and queens who gloried in shameless lust fiendish cruelty and pitiless misrule. It presented a sad picture of the rule.

\section{References}

Bamzia, P. N. K. (1994). Cultural and Political History of Kashmir (Vol. 1, p. 230). Delhi. 
Bamzia, P. N. K. (1994). Cultural and Political History of Kashmir (Vol. 1). Delhi.

Bates, C. (1873). Gazetteer of Kashmir. Kolkata.

Encyclopedia of Britannica. (1974a). Vol.10, p. 165.

Encyclopedia of Britannica. (1974b). Vol.12, p. 868.

Ganjoo, S. K. (1998). Kashmir History and Politics. Delhi.

Jayaka of Selyapure village was basically a householder; gradually he attained the position of a Damra (Landlord). By the revenue of his land and other business enterprises he became rich. Consequently he had purchased enough cultivable land.

Kapoor, M. L. (1992). History and Culture of Kashmir. Delhi.

Kapoor, M. L. (2005). Kingdom of Kashmir. Srinagar.

Kumudi. (1952). Kashmir Its Cultural Heritage. Mumbai.

Rabani, G. M. (1981). Ancient Kashmir. Srinagar.

Sharma, R. S. (2005). India's Ancient Past. Delhi.

Stien, M. A. (1979a). Rajatarangini of Kalhana (Eng. Trans Vol. 2, p.445). Delhi.

Stien, M. A. (1979b). Rajatarangini of Kalhana (Eng. Trans Vol. 4, p.191). Delhi.

Stien, M. A. (1979c). Rajatarangini of Kalhana (Eng. Trans Vol. 5, p.116). Delhi.

Stien, M. A. (1979d). Rajatarangini of Kalhana (Eng. Trans Vol. 6, p.162). Delhi.

Stien, M. A. (1979e). Rajatarangini of Kalhana (Eng. Trans Vol. 7, p.1100-1107). Delhi.

\section{Copyright Disclaimer}

Copyright for this article is retained by the author(s), with first publication rights granted to the journal.

This is an open-access article distributed under the terms and conditions of the Creative Commons Attribution license (http://creativecommons.org/licenses/by/3.0/). 